CIHM

Microfiche

Series

(Monographs)
ICMH

Collection de microfiches (monographies)

Canadian Institute for Historical Microreproductions / Institut canadien de microreproductions historiques
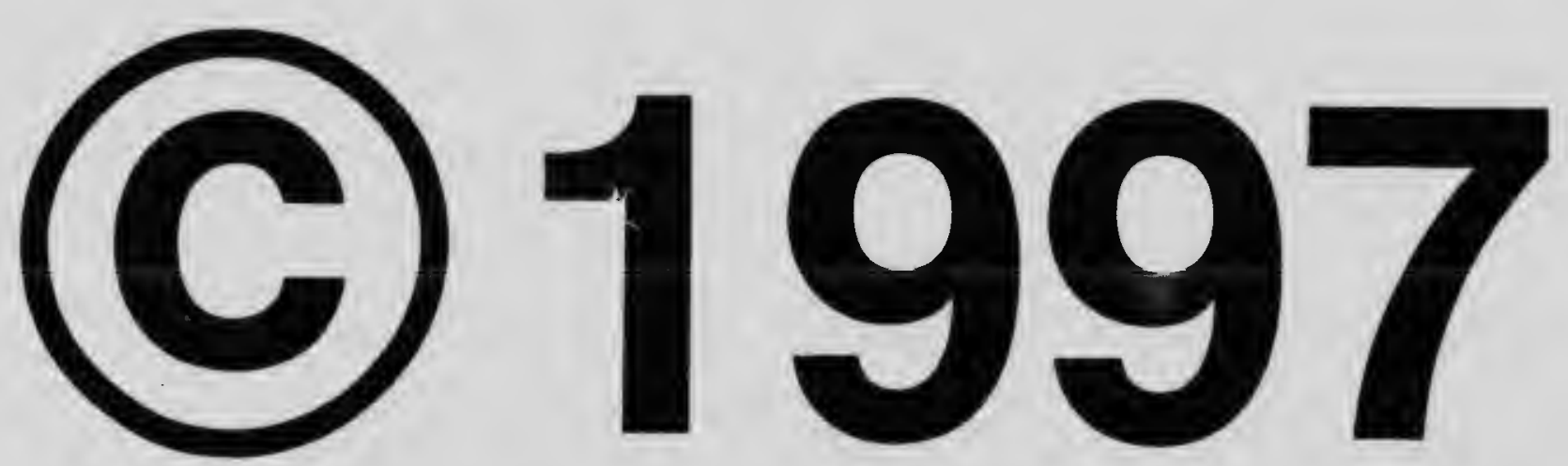


\section{Technical and Bibliographic Notes / Notes techniques et bibliographiques}

The Institute has attempted to obtain the best original copy available for filming. Features of this copy which may be bibliographically unique, which may alter any of the images in the reproduction, or which may significantly change the usual method of filming are checked below.

\section{Coloured covers /}

Couverture de couleur

\section{Covers damaged /}

Couverture endommagée

Covers restored and/or laminated /

Couverture restaurée et/ou pelliculée

Cover title missing / Le titre de couverture manque

Coloured maps / Cartes géographiques en couleur

Coloured ink (i.e. Other than blue or black) /

Encre de couleur (i.e. autre que bleue ou noire)

Coloured plates and/or illustrations /

Planches et/ou illustrations en couleur

Bound with other material /

Relié avec d'autres documents

Only edition available /

Seule édition disponible

Tight binding may cause shadows or distortion along interior margin / La reliure serrée peut causer de l'ombre ou de la distorsion le long de la marge intérieure.

Blank leaves added during restorations may appear within the text. Whenever possible, these have been omitted from filming / II se peut que certaines pages blanches ajoutées lors d'une restauration apparaissent dans le texte, mais, lorsque cela était possible, ces pages n'ont pas été filmées.

Additional comments /

Commentaires supplémentaires:
L'!nstitut a microfilmé le meilleur exemplaire qu'il lui a été possible de se procurer. Les détails de cet exemplaire qui sont peut-être uniques du point de vue bibliugraphique, qui peuvent modifier une image reproduite, ou qui peuvent exiger une modification dans la méthode normale de filmage sont indiqués ci-dessous.

\section{Coloured pages / Pages de couleur}

Pages damaged / Pages endommagées

Pages restored and/or laminated /

Pages restaurées et/ou pelliculées

Pages discoloured, stained or foxed /

Pages décolorées, tachetées ou piquées

Pages detached / Pages détachées

Showthrough / Transparence

Quality of print varies /

Qualité inégale de l'impression

Includes supplementary material /

Comprend du matériel supplémentaire

Pages wholly or partially obscured by errata slips, tissues, etc., have been refilmed to ensure the best possible image / Les pages totalement ou partiellement obscurcies par un feuillet d'errata, une pelure, etc., ont été filmées à nouveau de façon à obtenir la meilleure image possible.

Opposing pages with varying colouration or discolourations are filmed twice to ensure the best possible image / Les pages s'opposant ayant des colorations variables ou des décolorations sont filmées deux fois afin d'obtenir la meilleure image possible.

Thls ftem is filmed at the reduction ratio checked below / Ce documant ast filmó au taux de ríduction Indiqué cl-dessous.

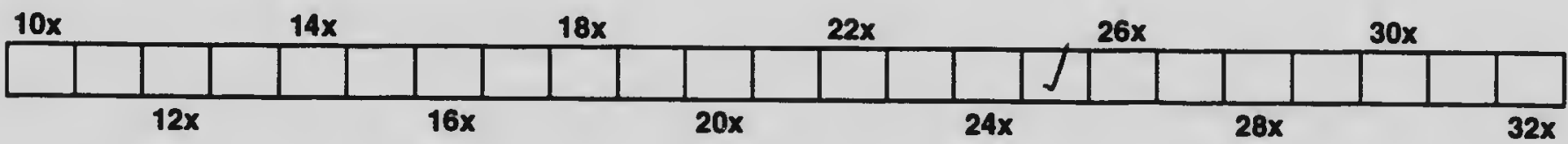


The copy filmed here hes been reproduced thenks to the generosity of:

\section{Stauffer Library}

Queen's University

The imeges eppeering here ore the best quelity possible con:sidering the condition end legibility of the orlginel copy end in keoping with the filming contrect specificetions.

Originel copies in printed peper covers ore fllmed beginning with the front cover end ending on the lest poge with a printed or illustroted impres. sion. or the beck cover when eppropriote. All other originel copies ere filmed beginning on the firse pege with e printed or illustreted impres. sion, end ending on the lest pege with $\bullet$ printed or illustreted impression.

The lest recorded freme on eech microflehe shell contein the symbol $\longrightarrow$ (meening "CON. TINUED\%), or the symbol $\nabla$ (meening "END"). whichover epplies.

Meps, plotes. chares, etc., mey be filmod ot different reduction retios. Those too lerge to be entirely included in one exposure ere filmed beginning in the upper lote hend corner, loft to right and top to bottom. es meny fremes as required. The following diegrems illustrete the mothod:
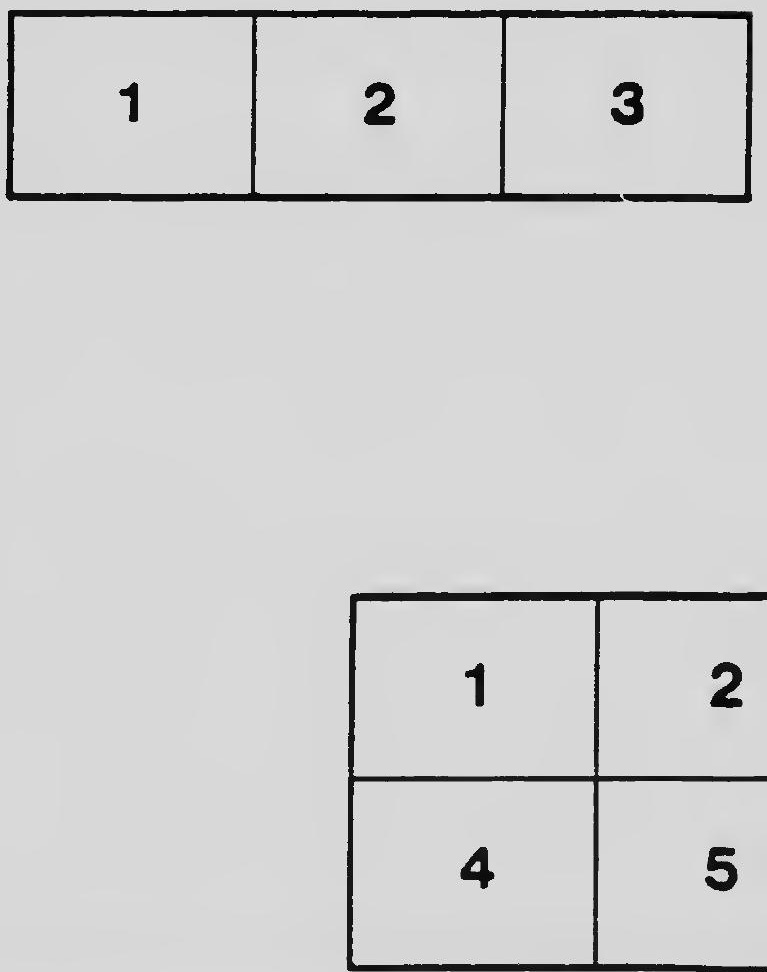
L'exemplaire filme fut reproduit gràce a la génorosité de:

Stauffer Library

Queen's University

Les imeges suiventes ont dib reproduites avec lo plus grand soin. compte renu de la condition er de le nertetd de l'axemplaire filmb. et en conformité evec les conditions du contrat de filmege.

Les exempleires origineux dont la couvereure on pepier est imprimde sont filmbs en commencent par le premier plat et en terminant soit par la dernitre page qui comporte une emprainte d'impression ou d'illustration, soit par le second plat. selon le ces. Tous les eutres exemplaires originaux sont filmes en commençant par la premióre pege qui comporte une empreint, d'impression ou d'illustretion et en terminane par lo dernidre pege qui comporte une relle empreinte.

Un des symboles suivents apparairra sur la dernidrs inrege de cheque microfiche, selon le ces: lo symbole $\longrightarrow$ signifie "A SUIVRE". le syrobole $\nabla$ signifie "FIN".

Les certes, plenches. tebleeux. etc. peuvent dere filmós des raux de réduction differents.

Lorsque le document est trop grand poup ère reproduit on un seul cliche. il est filmb a partir de l'angle supbrieur gauche. de gauche a droire. ot de haut en bes, en prenant le nombre

d'imeges ndcessaire. Les diagrammes suivants illustrene la móthode.

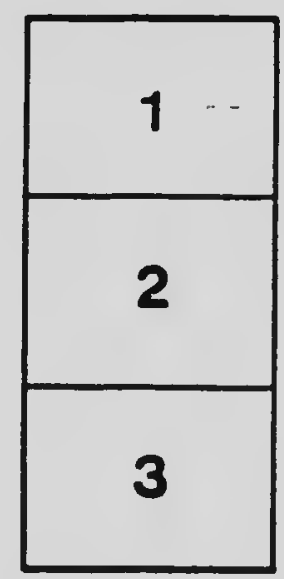

\begin{tabular}{|l|l|}
\hline 2 & 3 \\
\hline 5 & 6 \\
\hline
\end{tabular}




\section{MICROCONY RESOLUTION TEST CHART}

(ANSI and ISO TEST CHART No. 2)
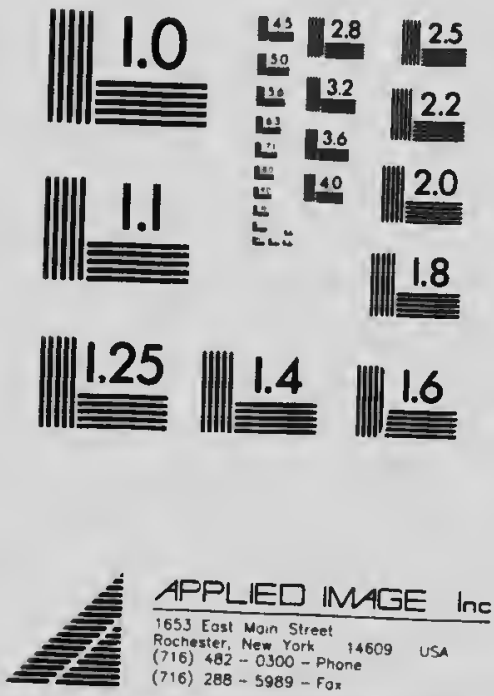


\section{R E POR T}

OF TIE

\section{CANAPIAN ARCTIC EXPEDI'TION 1913-18}

VOLUME VI: FISHES AND TUNICATES

PART B: ASCIDIACEA

By A, G. HUNTSMAN

SOUTHERN PARTY-1913-16
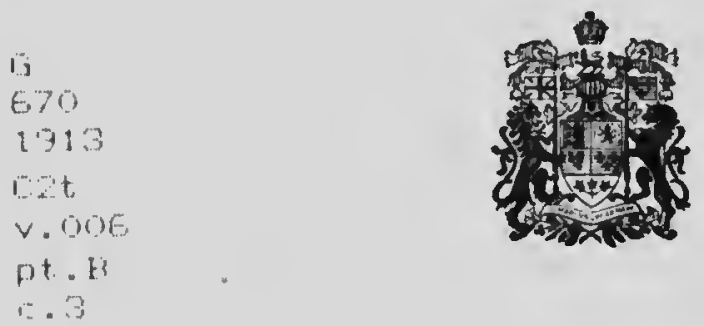

O'I LAIT

5. A MU.AND

PRINTER TO THI KIVG' WUNT LACI.LLENT MAJISTY 


\section{Report of the Canadian Arctic Expedition, 1913-18.

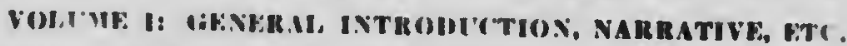

Part A: NolRTII

I'urt 13: sol'Till

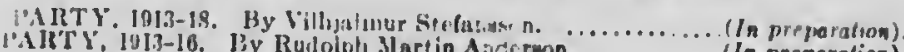

\section{VII.UME II: MIUMAL, AND aIRUY}

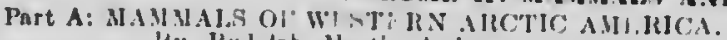

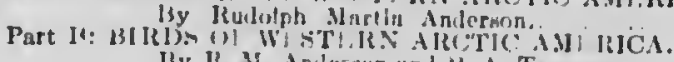

(In preparation).

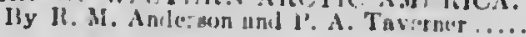

(in meparation).

\section{VOH.L:MV: III: IXSECT:}

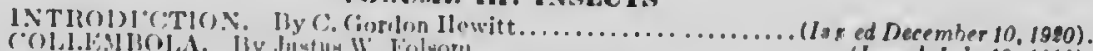

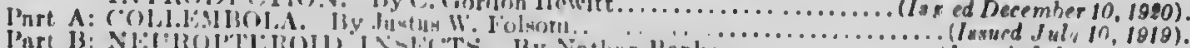

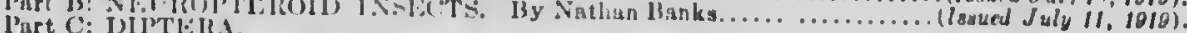

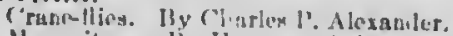

Mowguitues. liy llarremon (i. Myst.

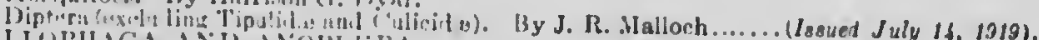

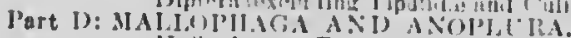

Inticiplatarit. By .1. 11: Baker.

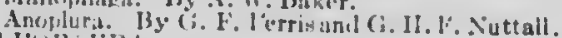

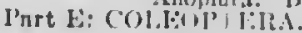

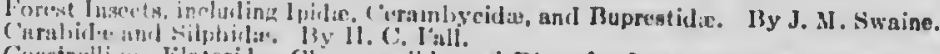

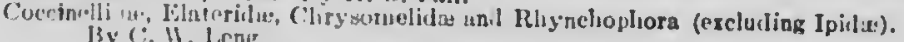

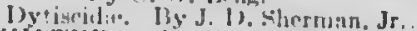

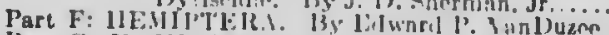

................ (Isoued December 12.1919).

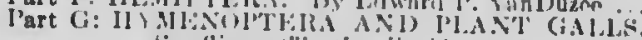
fun llies. (Pentlurellinenden). By Alex. 1). MacGillivray.

Inrusitic Ilymenoptera. Isjo Clarlen 1 . Brues.

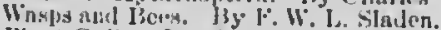

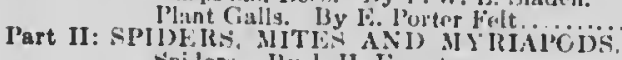

Spiders. Ily .l. Il. Eumerton.

Alites. 13 y Nathan IBnks.

Ml yriaporis. I3y Ralpls Y. Chamberlin.

Part 1: LEPIDOP'TRA. IBy Arthur (iileson. (Iseual January 10, 1020). (Iasued Seplember 4,1980 ).

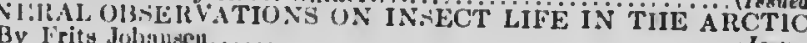

\section{VOLUME IV: IBOT.ANY}

Part A: FRESIIWATER ALGAL AND FRISIIWATER DIATOMS. By Charles W. Lowe.

Part B: II A Rive iI

Pnrt C: Feve A

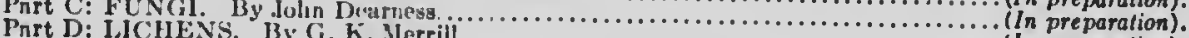

Part E: MOSSES. By

\section{VOLUME V: BOTANY}

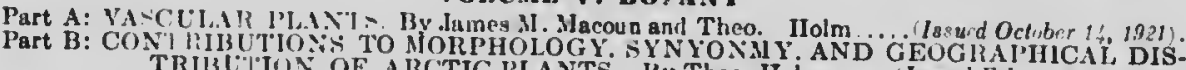

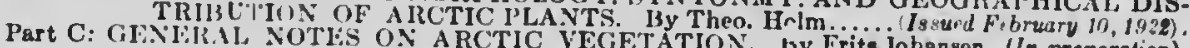

\section{VOLCME V: HSUES, TUNCATES, ETC.}

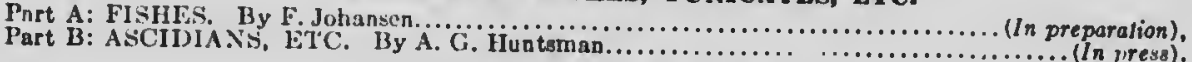

\section{VOLUME VII: CRUSTACEA}

Part A: DECAPOD CRLSTACEAX. By Mary J. Rathbun............ (/soued Aupust 18, 1919). Part B: SCIIZOFOD CRLSTACIANS. By Waldo L. Schmitt......... (Isoued September 22, 1819).

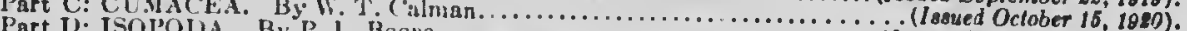

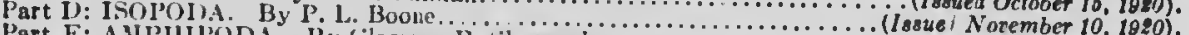

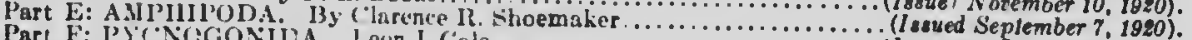
Part F: I'Y NGGONIIAA. I.cun J. ('ole........................... (In press, January 9,1921$)$.

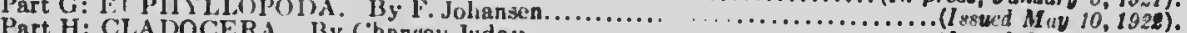

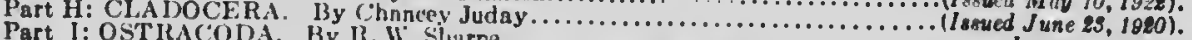

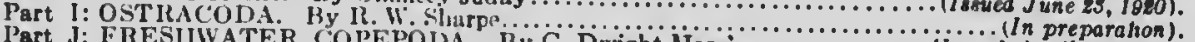

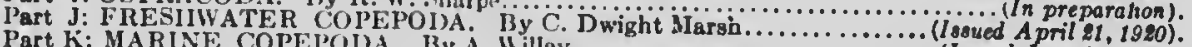

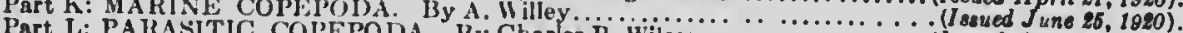
Part I: PARASITIC COI'EPODA. By Charles B. Wilson................. (lsoued Auguat 6, 1920).

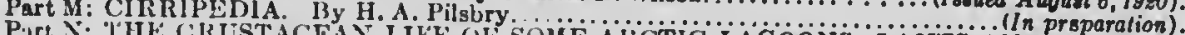

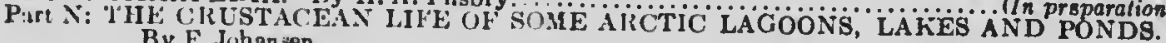

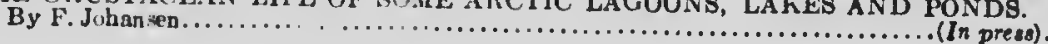




\section{REPOR T}

OF THE.

\section{CANADIAN ARCTIC EXPEDITION 1913-18}

VOLUME VI: FISHES AND IUNICATES

PART B: ASCIDIACEA

By A. G. HUNTSMAN

SOUTHERN PARTY-1913-16

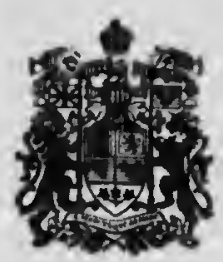

OTTAWA

r. A ACLAND

PRINTE: T TO THE: KING'S MOST FXCLLLENT MASHSTY 14?2? 


\title{
Arctic Ascidians.
}

\author{
13r. A. (i. Hextanav

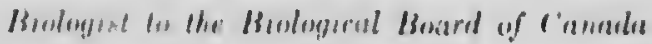

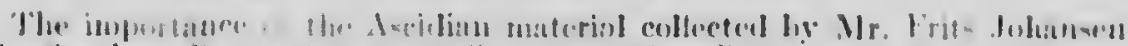

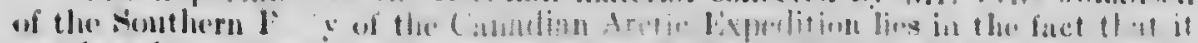

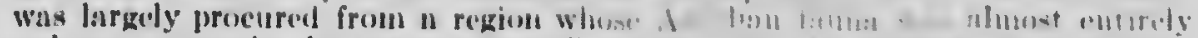

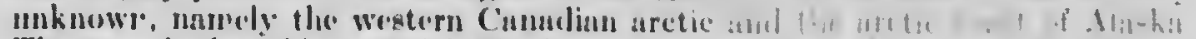

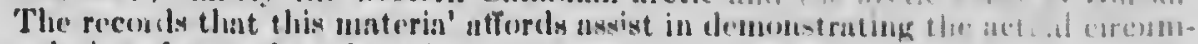
polarity of a nimber of species.

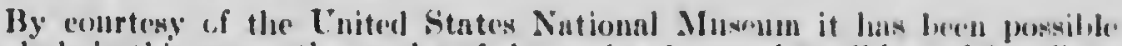
to include in this report the results of the stucly of severnl small lots of Areulians

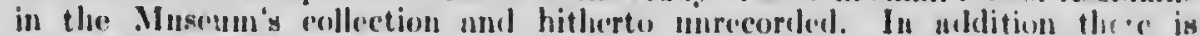
includeri a single record from uretie material of the Conndian Fisleries Muscum.

The data for the stations of the Canndian Aretic Bxpedition at which

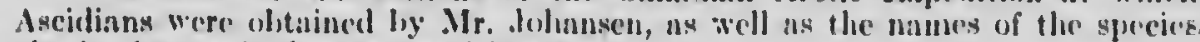
olstait. d at each place, are as follows:-

Station 20 b and $c$. (iranthy larhour, Alasku, 2-33 fnthouns, sumly mull, July 30), 1913. shizomolyulu vlobularis.

Station $20 \mathrm{~d}$. Gruntley hurhour, Alaska, head, July 31, 1913. Rhizomolgula globularis.

Stution 2l, d, e, and $g$. Fanst of Cape Lisbume, Mlaska $\left(68^{\circ} 48^{\prime}\right.$ X. lat., 16i: $10^{\prime} W^{\prime}$. long.), plankton tow, in surfuce, August 16, 1933. Rhizomolgula globularis.

Station 22. Southwest of Pint Lay, Alnskn, $\left(69^{\circ} 35^{\prime}\right.$ N. Iat., $163^{\circ} 27^{\prime}$ W. long.),

11-12 fathonis, rock and sant, August 17, 1913. Chelyosomi macleuyanum.

Station 23. Northeast of Icy cupe, Alaslan, (70 $24^{\prime}$ X'. lat., $161^{\circ} 25^{\prime} \mathrm{W}$. long. ), 9-10 fathoms, mud and pibhles, August 19, 1913.

\section{Trididemum tencrum.}

Didemnum albidum (":)

Chelyosoma macleayanum.

('ystingia griffithsii.

Goniocarpa lovenii.

Goniocurpa rustica.

Bollenia echinala.

Station $27 \mathrm{~d}$. "ay at Collinson point, Alaska, 0-1 fathom, gravel and tundra debris, September 15, 1913. Khizomolgula ylobularis.

Station 27 s. Camden bay, Collinson point, Alaska, 3 fathoms, sandy mud and gravel, Octo ier $3,1913$.

Rhizomolgula globularis.

$4131 \%-1 \frac{1}{2}$ 
Station 37 b. Inume latrour at Bermard harbonr, Dolphin and Cinon strait,

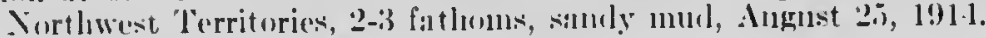

('ystimgin griffillsii.

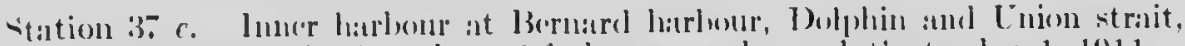

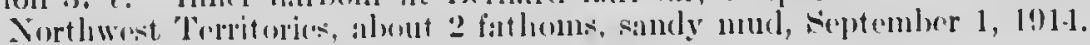

Rhizomolyula elobularis.

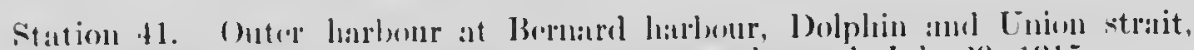

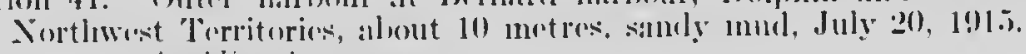

Iscielinjusis prummm.

(ystimgle! !rifflhsii.

lillizomul!!mla ylobularis.

Station 43 a. Dolphin and Lnion strait, Sorthwest Territories, ahout 100 motros, silndy with pobbles, september 13, 1915.

("ysingia miffillsii.

Station 133 b. Dolphin and Junon strait, Northwest Territories, il)-60 metres. :and: mud with pelbles. septembel 14, 1915.

C'ncmidocarpa rhizopus.

Sitation 43 c. Dolphin and Linion strait, Northwest Territorics, 201-30 motres, gray mud and stonc's, Sirptember 14, 1915.

Styelopsis sp. (?).

Station 50 d. Young point, Dolphin and Lnion strait, Northwest Torritorios. 0-1 fathour, rock, July 21, 1916.

styclopsis sp. (?)

\section{Aplidium spitzbergense llartmeyc}

ig0:3. A plidium * pilzbergense, HartuFyer, p. 341.

1908 b. Amaroucium sarsi, BuErkan, p. 92.

1912. A plidium spilzbergcnse, Hextswax, 1) 137.

West const of MeClintoek island, Franz Josef lanul, $\left(80^{\circ} 22^{\prime}\right.$ I. lat.), July 1902, Baldwin-Ziegler expedition, U. S. Nat. Mlus. No. 6640, 2 colonies.

In the smaller colony $(20 \times 15 \times 8 \mathrm{~mm}$. $)$ the zooids are at most $5.7 \mathrm{~mm}$. long, and no eggs or embryos eould be found. In the larger one $(28 \times 20 \times$ $10 \mathrm{~mm}$.) the zooids were as long as $10 \mathrm{~mm}$., and hoth eggs and embryos were observed. The difference in the length of the zooids appears to be tue wholly to the postabdomen, the abdomen and thorax heing virtually of the same length in individuals from hoth colonies.

There are four rows of stigmata with ahout twelve stigmata in each row, three dorsal languets, and three gastrie folds. The languet in front of the atrial aperture varies mueh in length and may be rither simple or forked.

There seems to be no essential difference between Bjerkan's species, whieh he plaees in the genus Amaroucium, and that described by Hartmeyer. The differenees hitherto given as a basis for separating the two genera are not suffeient for dividing the speeies listinctly into two natural groups, and revision is much needed.

The distribution of this species is similar to that of a number of other Aseidians and may le defined as being nearly throughout the Atlantic aretic and subarctic regions. 


\section{Trididemnum tenerum (Verrill)}

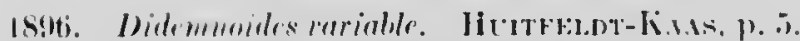

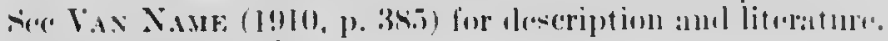

Station 23, one rolony

So spicules worc fonnd in the single colony uhtuined. (inlony $34 \times 18 \times$ T mm.; incliviluals alont $1.5 \mathrm{~mm}$. long: oral aperture (i-lobed; the atrial without languret on a tubular siphon and indistinctly lolenl: thre" rows of stignata, about 12 in each row; two dorsal languets on transierse veriscls of loft side; testis with eoiled vas duferens on outer surface.

This is an aretic spreies, which is doubtless eiremmpolar, the presunt reourd tencling to comnet the known distribution in northern European seas and the dsian aretie ocean with that along the east eonst of Aneriea from Newfommland to Cape Cod.

\section{Didemnum albidum (Virrill) (?)}

Sre Vix Nane (1910, p. 378 as Tetralidcmmm albidum) for description and literature.

sta. 23, 3 colonies.

The very small sizo of the eolonies in the collection has provented a position identification. In the eharacter of the spienles and in suel dretails of the structure of the zooids as could be determined they agree with the description of this species given ly Nan Name.

This is a very definite extension of the known clistrilution of this speries. which hitherto has heen found only in the Atlantie portion of the aretic and subaretic from spitsbergen and the Murman eoast to Davis strat and (ape Coul. Ifartuneyer has, howeror, recently (1921, p. si) reportorl it from the siberian arctic coast and Bering strait.

\section{Ascidiopsis prunum (U. F. Müller)} ature.

See VAx Nawf (1912, p. 599 as Phallusia prumum) for description and litol-

Sta. 41,4 specimens. - North Greenland, eoll. P. II. Sörensen, I’.. lat. Mus. No. 6632, 1 specimen.

This is a widely distributed circumpolar form. As Hartmeyer lias surmised, it occurs in the northern Pacifie, and I expeet to publish shortly an account of its synonymy and distribution there.

\section{Ascidiopsis dijmphniana ('Tr:mlstelt}

1886 Phallusia dijmphniana. Traustrot, p. 424.

1903. Ascidia dijmpliniana, IIAltmerer, p. 293.

therdare clanmel, east of Alger island, Franz Josef laml, Jume, 1!101, Baldwin-Ziegler expedition, U. s.. Nat. Mus. No. 6639, I specinı'u.

As this species has not been very thoroughly described, an account of this well preserved specimen from Franz Josef land is desirable.

In size, $34 \times 24 \times 14 \mathrm{~mm}$. The animal is oblong in shape and is attached by the posterior part of the left side. The surface is extensively wrinkled and shows seattered, minute papilla $0.1 \mathrm{~mm}$. in diameter, and from 0.1 to $0.3 \mathrm{~mm}$. long, in which terminate many of the ressels which are abundant throughout the test. These papillae are best developed and most numerous near the apertures, but are present over the entire unattached portion of the test. The apertures are both at the anterior end, the oral in the centre and the atrial at the dorsal angle. The lobes are provided with many scattered. short papillac. and number seven for the oral and six for the atrial. 
Test from 0.3 to $1 \mathrm{~mm}$, thick, pliable, translueent and raseular throughout. The main vessel enters the test on the left side near the postere-ventral angle of the body. The principal branches take alnost parallel eourses toward the anterior end, exeept that a large vesed procecels along the loft side dorsally, passes letween the siphons, and. turning backward on the right side, loreaks up into four pasallol branches and supplies nearly the whole of the ant (ero-rontrat half of the test on that sille.

The tentacles numbur 66 and the prestigmatic zore is smonth. The dorsal tublerele is in the forn of a simple horseshoe, with the broal opening between the horns directed forwards. The interior lip ol the peripharygent groose is very broad near the tulurcle, and partly covers the latter. The dorsal ganghion is cheser to the tuberrile.

The dorsal lanima is ribhed on both siles as far as the oresophageal area, but only on the loft sicle farther hack. Its margin is coarsoly toothed or laceiniate, the terth rolresponding to the ribs of the loft side. There are occisional intemediate treth. The lamina extends a considerable distance behind the orsoplangeal aperture. The accessory lamina on the right side of the ocsiophageal area is ribbed on the right side and has terth eorresponding with the rihr. The pharynx extends abont 7 mm. behind the oesophageal aperture.

There are 60 longitudinal hars on the right side, and isis on the left. There arr small papillae at the junctions of hars and trumswrec vessels, and also intermodiatce papilla in most pasts of the pharyengal wall. There are about two longitudinal harz for eacle plication of the wall. The stigmata are three to six in number for each mesh.

The intestinal eanal ocempies nearly two-thirds of the left sicle of the hory from the posterior end forwards, and is much onscured by the rather thick coating of elosely placed renal vesicles. The stomach is short, broach, transversely placed, and apparenty with seven folds on the right sille. The intestine takes a rather evenly curved s-shaped course to end at the base of the atrial siphon in the anus, which exhibits a bibhed reflexed margin.

The eomplexly branched ovary is situated in the first intestinal loop and "xtensively envers the right side of the first linb of the intestine, but extencls only slighily over the left side of the latter. Tistes were not seen. The wriduet crosice the last bend of the intestine, and then acenmpanies the rectum along its dorsal side.

Hartmeyer (1919, p. 131) has expressed a doubt as to the distinetness of this species from $A$. prumum, and believes individuals of the latter speeies which lic has seen show intermediate conditions which eonnect the two. To the eh:isactors which have been given by Hartmeyer (1903, p. 293) for distinguishing the two speries, I would add two, namely the presence of minute papillae scattreel generally over the surface of te test in A. dijmphniana and their alsenee in A. prumum, and the number of longitudinal hars (15 to 20 on each side in the litter, and more than 50 in the former). Although the two species may teml to intergrade in other characters, it is suggested that in these two respects they inay always be distinguished.

This recort extends only slightly the known distribution of this species, which has been found in the aretic seas to the north of Russia. However, material collected hy Dr. E. M. Kindle on the Labrador coast in 1921 contained a single specimen of this species, whose distribution is cloubtless fairly extensive in the Atlantic portion of the aretic and sub-aretic regions. 
Chelyosoma macleayanum Brod. : and Sow.

See H.ntmeyer (1903, p. 269) and Vax Nimk (1!12, p. 591 ) for description and literature.

Station 22, 2 specimens.- Station 23, 11 specinens.

This well known species is a chatrateristic aretic cireumpolar form, but is

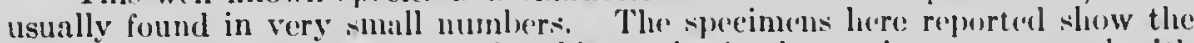
usual large size that is attained ly this species in the aretic, as eompared with the subarctic. All hut two of the specimens were from 16 to 37 lum. long. Their growth has been studied (1lunt-man, 19)21).

\section{Molgula septentrionalis Trausterlt}

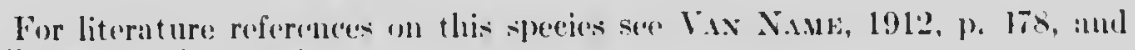
Redikorzew, 1916, p. !1.

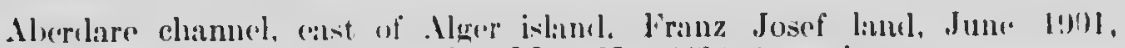
Baldwin-Ziegier experlitiou, I's. Nitt. MIn.. No. bi63!), I specimen.

This species has previously been reeorded from spitshergen, as woll at: from othe points in the Atlantic portion of the aretic from Fovilya Zemlya

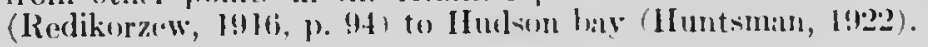

Cystingia griffithsii M:ı lal:!y

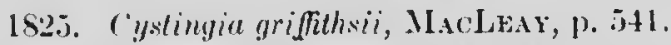

1842. Clatelina chrystallina, Miolliz, 1). 95.

Pera, Molgula, s. Cuesim crystallina, auct. v:ir.

Station 23, 5 specimens.-Station 37 b, 14 specinens. - Stat ion +1 , 4 specimens.-Station 43 a, 1 specimen (test only).

In 182:5 Macleay described three species of Ascidians that had been collected by W. $\mathrm{N}$. Ciriffiths at Winter island in Fox clannel on Cant. Parry's second arctic voyage. 'Two of these are well known aretie forms (Boltenia and Dendrodou). The third, which he called Cystingia uriffithsii, hiss not sinee been recognized among aretic or other inaterial of Ascidians. It his heen considered as belonging to the family Tethyidae (Cynthiidae), and to be near the genus Fungulus. Hartmeyer has, however, (1903, p. 185) called attention to the fact that an organ of this species described and figured hy IacLeay resembles the renal organ of Caesirids (Molguliets). As this form was obtained in the sane general region as that explored by the canadian Aretic Expedition, it seemed probable that Cystingia might be found in the matorial brought back oy that Expedition. After working over that material, I turned to .Iacleay's figures and description of Cystingia, and it was at once apparent that MacLeay's Cystingiu griffithsii was none other than a somewhat unusual sprerimen of the now wroll known ('aesira (Molgula) crystallina, first lescribed by . Möller in 1842 from Greenland.

MacLeay's description and figures were not sufficiently clear and accurate to have prevented error concerning the systematic position of this species. The unusual structure of the stalk of his single srecimen lats prophips contributed to the failure in the identification of his species with $C$. crystallina. One of the specimens collected by Johansen has a similar stalk, with the attached arca and "roots" along one side instegd of being, as is usual, at the distal end. In.lividuals with intermediate conditions were also brought back by .Johansen. 


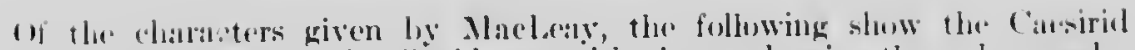

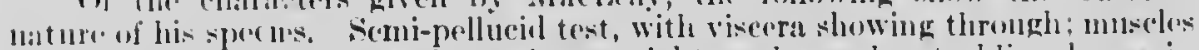
only (?) near apertures, and crossing at right angles and not oblighnely, ats in Bolleniof fur exampho; branchial moshes irregular (as compared with Boltenill :mol Dendroloa); a rousl organ-"diaphamous longitudinal ponch" containimg "two Lhackish nodules"- present and on right side; and left gon!ll al wro intestinal lo(1). 'Two characters given by Macleay do not agree with those of Carsiridk. These are the d-lobed oral aperture and the absence of a liver. In this speein's the oral aperture has three lobes on each side, and of these the posterior is the nost prominent, after that the anterior, while the middle one is relatively small. In a certain state of contraction, the midcle lohe is distingnishad with difliculty, and the four atrial lobes are at the same time equally indistinct. This is suflicient to explain Macleay's deseription of the "branchial orition" an

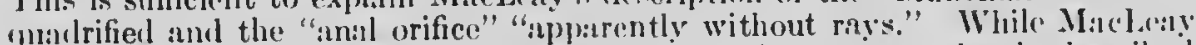
states that his species "lass no liver very distinct," the structure that lad described and figures as the leart is douldeses the liver. The latter is well depieted (althomgh not nanued) in position, form, and shade, in his figure 4.

In favour of the identification of MacLeay's species with $C$. crystallina, we latre the gencral shape, the sizo, the charactor of the surface, the presence and character of the stalk, and the positions of the two apertures. Also the two vaseular processes (one is brokent) which pass into the stalk, an' reprosited in his figure 4. He states, however, that "the branchial pouch las alont fourteen folds," whereas C. crystallina has been described as having only ten. 'Tlere condition of MacLeay's specimen apparently did not permit of aceurate de.tirmination of the number. Nevertheless, in support of Maclary's virw as to the indetiniteness of the number, we have in this species what aphears to have been orerlooked, namely that there are in reality more than ten folds. In fact there are fonrtecn rows of infundibula, and therefore fourtem folds. Tlue most dorsal and most rentral of the left side entirely lack longitudinal hars. which renders them insignificant in comparison with the others, which possess from three to four. On the right side the most ventral is without har and the most dorsal with one only. Thie formula of cne specimen is:-

I.eft. Dors. $0(0) 0(4) 0(4) 0(4) 0(3) 0(3) 0(0) 1 /$ Vent.

Kight. Dors. $0(1) 0(4) 0(4) 0(4) 0(4) 0(3) 0(0), 0$ Vint.

Another point worth noting is that Macleay refors to the limanchial folds being transverse in position rather than longitudinal, and this is indered theri. positiom.

In view of these facts there can be no rensonable doubt as to the iulentity of MacLeay's species. The name he has given must, therefore, replace Möiler's name chrystallina.

The position of the testes in this species deserves consideration. Both Van Nime $(1912, \mathrm{p}, 495)$ and Oka $(1914, \mathrm{p} .444)$ fignre them as grouped along the anterior half or two-thirds of tl.0 ovary. The latter also describes a new species (Molgula redikorzcvi) similar to this one, exeent that the testus are separated from the ovaries and hie, those of the right sic. those of the left side in the intestinal loop, as (1916) figures the testes in crystallina (p. 6i2) at the . terior end of (ach ovary, and in redikorzevi (p.67) on the right side from the anterior end of the orary around the anterior end of the renal organ and lofow it, and on the left side in, below, and on the inner side of the intestinal loop. I have fouml that in one large and nine small specimens from Bernard harbour, the testes are almost invariably at or near the anterior end of the ovary, but tend to extend down in front of the renal organ on the right and the intestinal loop on the left. In one specimen on the left side they are on the outer side of the oriduct, that is at 
the posterior end of the ovary, while oun the right sile they are at the anterior

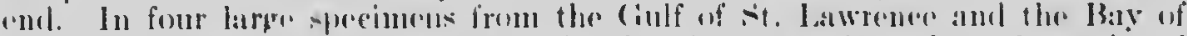
Fimdy the position of the tostes raries, hot in mo specimen latre I pert foumd

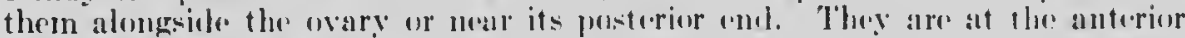

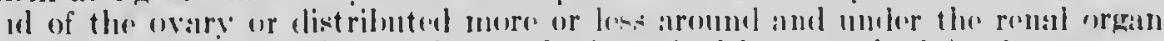
on the right side, and into or heluw the intestinal lowp on the heft, the extreme

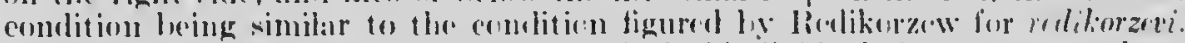
Whether this latter eombition is more typieal of individusts from mone soltherm

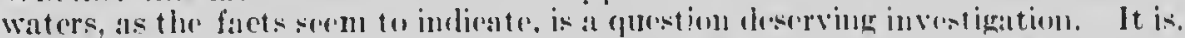

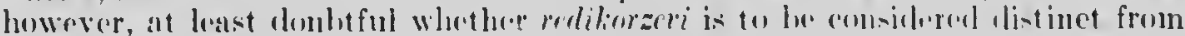

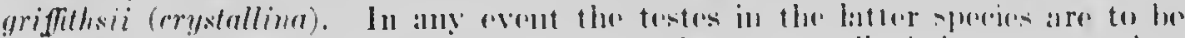

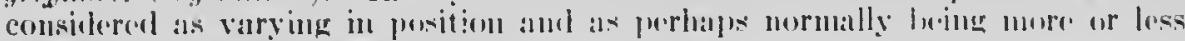
soparatiol from the oviry.

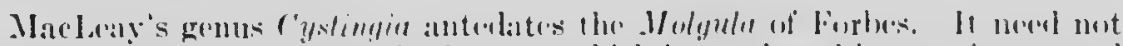

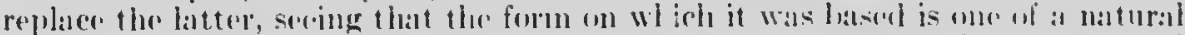

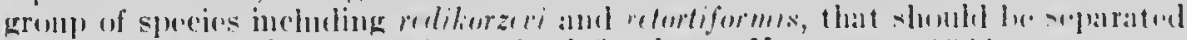

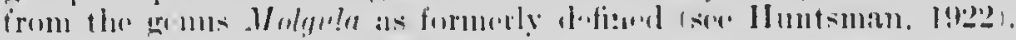

\section{P:hizomolgula globularis l lillin:}

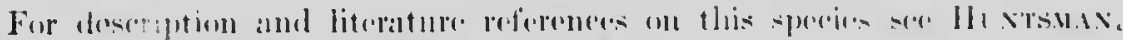

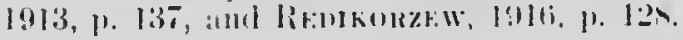

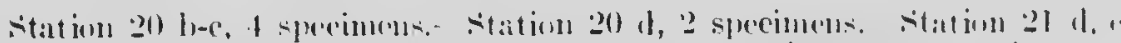

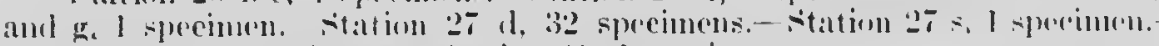

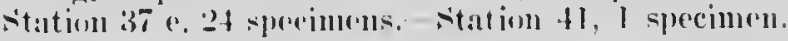

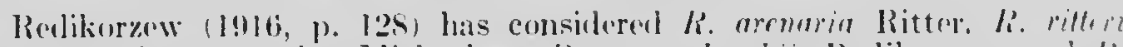

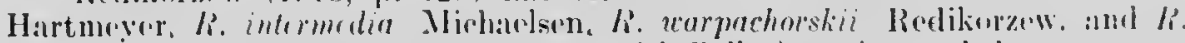

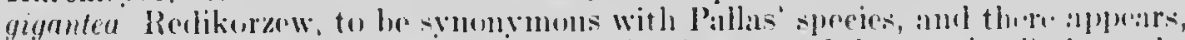

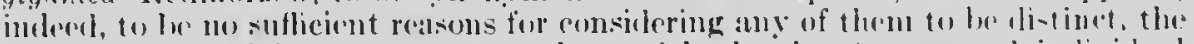
differences moted heing no greater than might be due to age and individual variation.

Material at my disposal eomes from tabrador, lludsun hay, James haty,

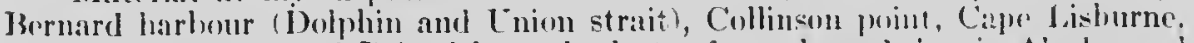
Grantley harbeur, and Jristol hay, the latter four places lueing in .lasisa and at widely separated points from unerh to south. 'The material from Bristol hay

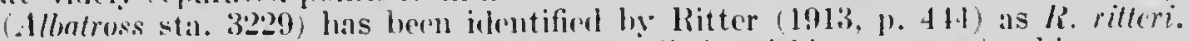
Of the characters that have hem gionn as distinguishing surees in this gemes, none seems to he sufliciently definito and invariable to hase divisions upon. The amomint of sund envering the surface depends upon the nature of the buttom, in some places being entirely alosent. The shape varios eonsiderahly depending to some extent mon age and state of contraction. The elongation mily he paraliot or at right angles to a line from the attached to the free conl. Finere may or may not le lateral flattening. "lhe "root" for attachment may he simple and small or much-hranched and extensive. The museuiature is perhaps relatively more powerful in large individuals and appears heavier in contracted specincis. Its arrangement I hate alrcady desoribed (Iluntsmin, 1913, p. 137). The tontacles vary in num! nd size. The dorsal tubercle has the aperture between the horns dirceted $n$ om dircaty anterior to ahost directly to the left. The pharyngeal folds are more or les- prominent, depending upon the state of contraction and the method of , resriation. The number of bars 111 each longitudinal fold is $i$ more varibita litum is usual in Caesirids, and the small differences elaimed as important camnot be considered significant. 


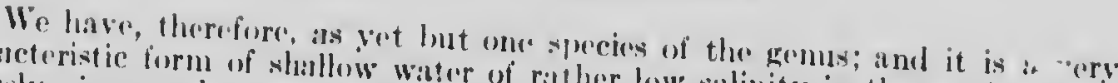
characteristic form of shallow water of rither low sathinity in the aretic. It is

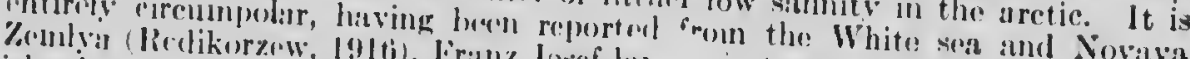

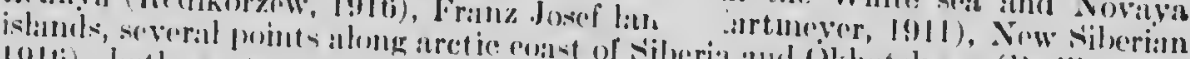

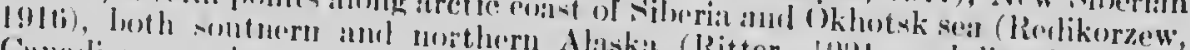

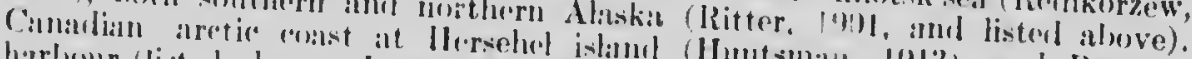

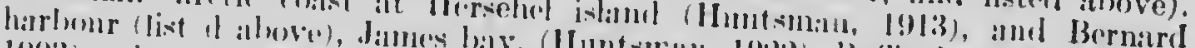

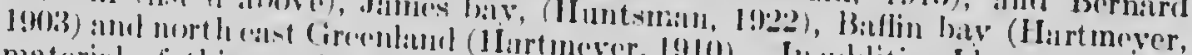

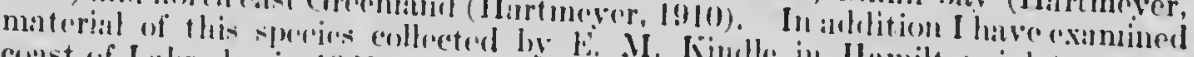
const of Labrator in 19:2l.

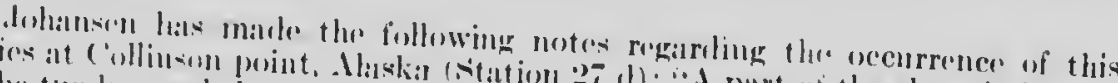

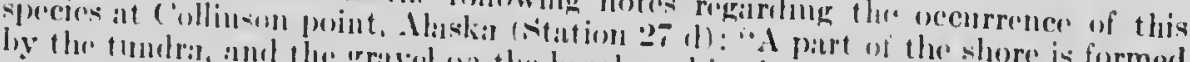

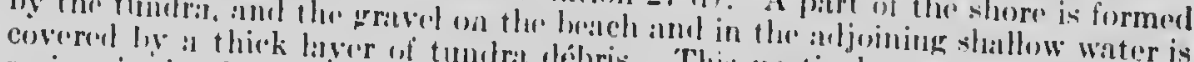

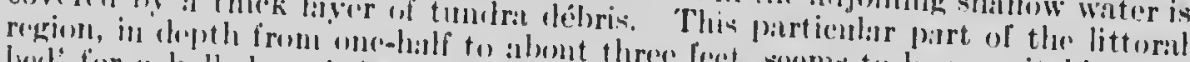

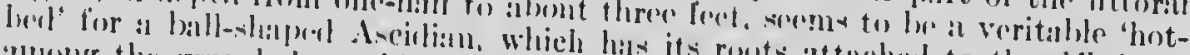
anome the gravel. Int which I wisch his its ruste altached to the debris or

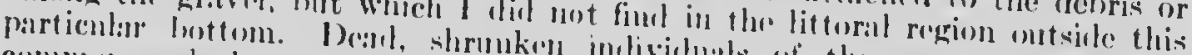

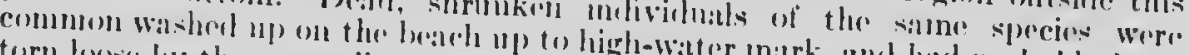
torn lonse ly the watere."

\section{Kukenthalia borealis ( $($ int twellathlt)}

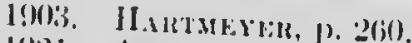

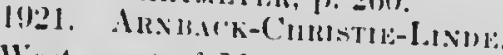

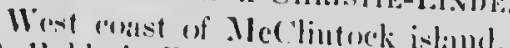

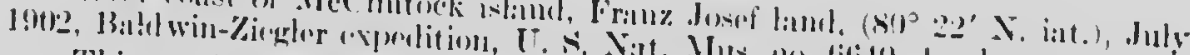

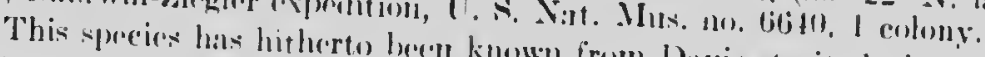

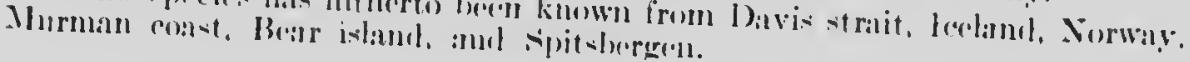

\section{Styelopsis +1). (?)}

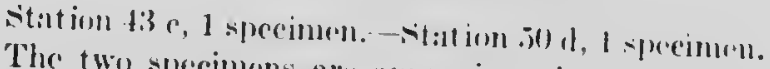

The two specinens all approxinutely 2 mm. long and I mm. high. d. they are immature and these structure cimnot be fully clotermined, it would sany described forme them specifically, coren thomgh they srem to differ front

In the first sprecimen the surfuer is encerent with

The alpertures are at rither end of the free both to be 4-lolwel. The test is thick an arface on short siphons and seem well devolopel and ensists of the two usual lavernt. The musculature is sinple and short. The dorsil hanina is tout layers. The oral tentacles are bars on each sicle. No atrial ter eles toot..ed. There are five longitudinad horizontally placel on the left side, cles have been found. The stomach is finally ascending to end in the anu. id the intestine turns to run paralle! to it, gonad on the right side, which is vertically. (he al aperturc. There is a single the anterior end. It consists of a cent willy (dirso-ventrally) oriented and close to

In the second specimen the surface and scveral testes along the inargin. No lobes could be discornol for the supertures wrinkled and not sand covered. opaque. There are 4 or i) clorsal langertures. The test is thin and somewhat the right side of the pharvinx and is on the left. There are 6 longitudinal bars on of pharynx extenching dorio-ventrally, the left. Ahout 20 stigmatia on each side stigmata, lout nonc of the latter elongaterl antoro-posteriorly. Hout 6 gastric
foids. Anus with smooth margin. 


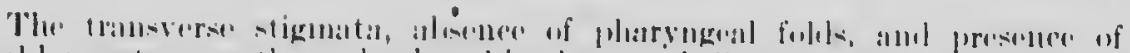

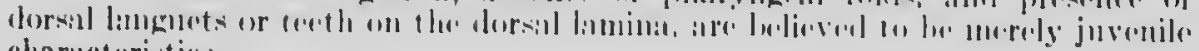
charateteristies.

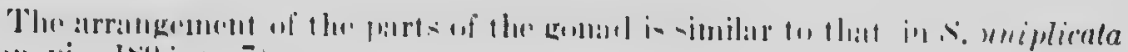

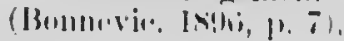

\section{Dendrodoa adolphl (linptïr.r)}

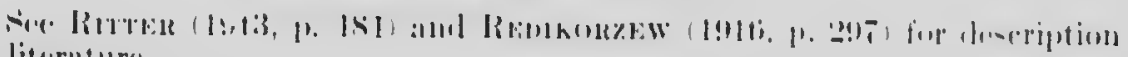
and lituriture.

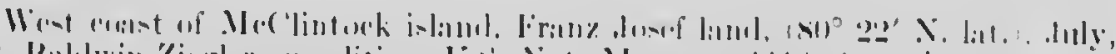

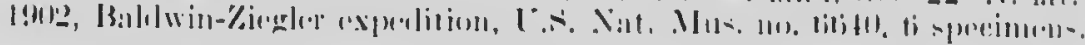

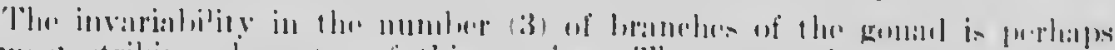

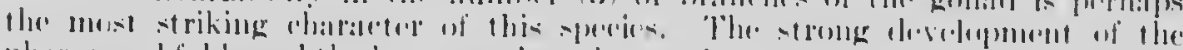

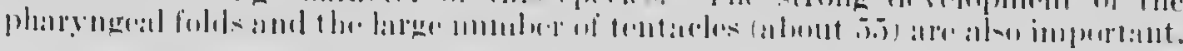

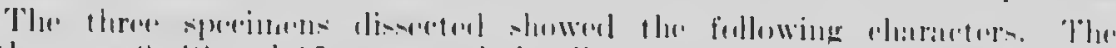

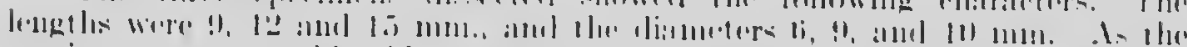

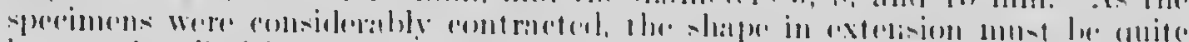

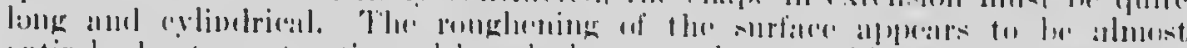

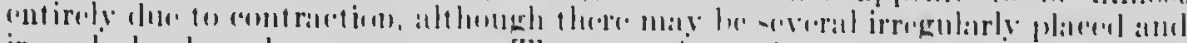

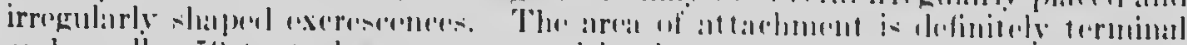

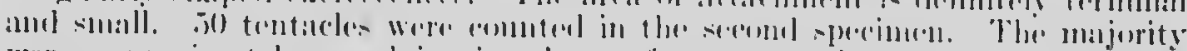

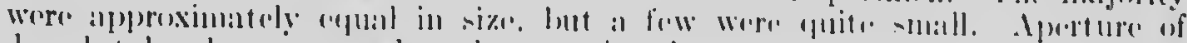

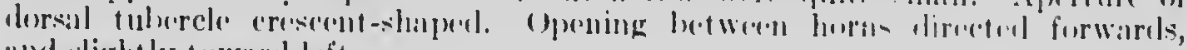
and slightly towatrd left.

liormula for liars on pharyngenal fokls.

\begin{tabular}{|c|c|c|c|}
\hline . Right. & Dors. & () (8) $1(4) 1(6) 1(4) 1$ & \\
\hline 2. Righ & “6 & () (6) 1) (9) 11 (7) 11 & \\
\hline ling & " & $1(12) 0(.5) 0(8) 0(6) 0$ & \\
\hline Right. & “ & 1 (!) 1 (4) I (8) 1 (i) 1 & \\
\hline & " & (1) 1 (1) $1(7) 1(5) 1$ & \\
\hline
\end{tabular}

(iantric fidk from 24 10:30) in mumber. Intestine varying much in rurvature. In the first specimen it leends back to run barallel to and elose besifle the stomach and continues in an almost straight but short course to the anus. In the third specimen it takes a short s-shaped course, the finil part paralleling

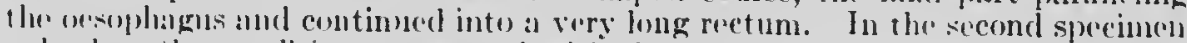
only anes the comdition correspond witl that elescribel hy Ritter, that is with the first part minking an eren corve aroumet to the owsophagus, atmel then bending rather sharply forwarels and downwards.

The necessity for a revision of the surecies of this gemes has lexen repeaterlly minplasizal. Si) one seems yet to have had sufficient material for this purpose. Although I have reforrerl these specimens to Kupfer's species, it is highly probable that the latter is illentical with $D$. kükenthali Hartmeyer (1899, i). 193) and ('ynthiu pulchella Verrill $(1871,1)$. 98). The latter has becen well de'scribed iy lin S:me (1912, 1. is1) as D. aggregata var. pulchella. If these sprecies are synonymous, Verrill's name will have the priority. 'The differences that have lieen noted hetween these forms lo not seem to be very important, having to do with the numbers and sizes of the tentacles, numbers of longitudinal hars, orientation of dorsal tubercle, munber of gastric folds, and comrse of intestinc, all of which vary greatly from individual to individual. With such limited matcrial at iny disposal, I 'resitate to unite these forms.

I). adolphi has been recorded from north-east Greenland, Bering sea, and the (inlf of Tartary; D. kükenthali froun Bering sea, Siberian Arct ir ocean, Liur: sea, and snitsbergen; and $D$. pulchella from Newfoundland to the (If of Mine. 


\section{Cnemldocarpa rhizopus (IPelikur\%w)}

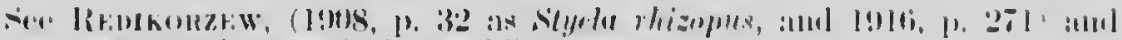

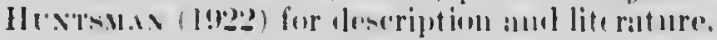

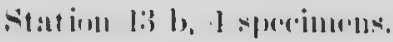

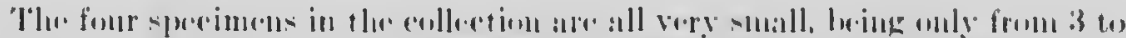

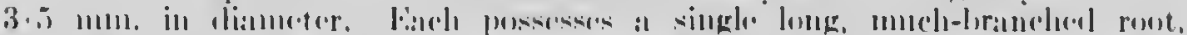

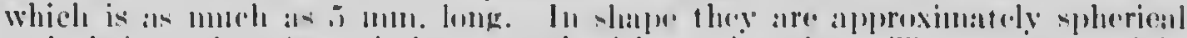

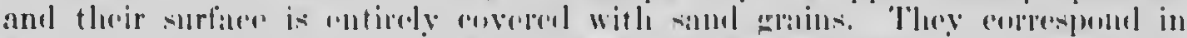

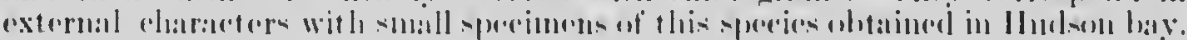

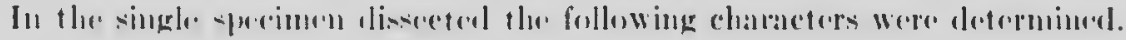

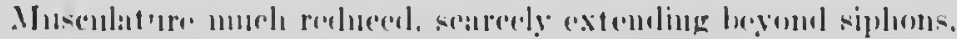

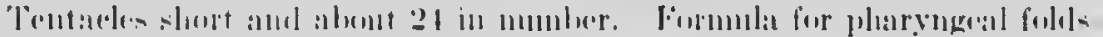

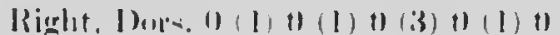

l.oli. . 1) (3) $10(1,0)(3)$ ) 11 (1)

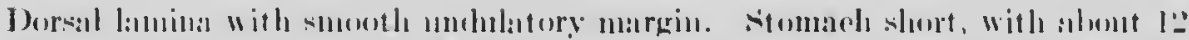

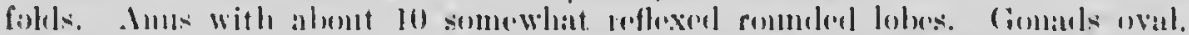

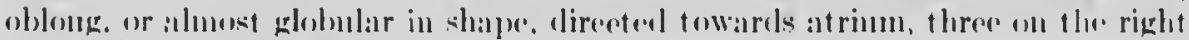
sidle :Iud t wo on the laft.

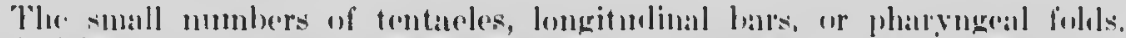

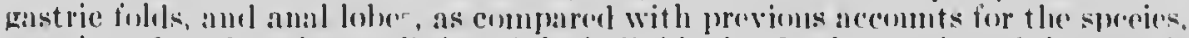
nay he referend to the smatl size of the inelivilual. In the mumber of the gombles there is : grerement with IIndson hay sperimens (Huntsnam, 102:2).

'The records of this speoies, thomgh fow, inclicate a rirenmpolar distribution

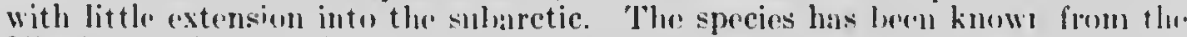

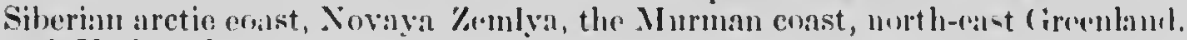
and Ihulkon h:!̣y.

\section{('sniocarpa lovenil (hill, if l):ıl.)}

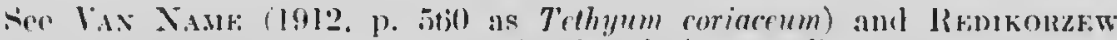
1916, 1). 24.4, as (ioniocarpe coriacra) for description and literature.

station 23. 4 speeinens, - Cape lisburne, dlaskin, ij-10 fathous, sand and graver, coli. W. H. Mall, (.... Nint. Mus. No. 6647, 1 specimen.

F.lawhere (Huntsman, 1922) I have expresed an opinion on the distinctnoss of ertain of the forms that have been unitel with this speeies hy Redikorzow (1916) and Hartmeyer (1915). They are indeed noarly rolatuil and the majority have not yet been clearly showin to be distinet. "There is certainly very eonsidesahle individunl variation in both external and internal characters. The aretic specinens listed above do not differ essentially, so far as examined, from specinens taken along the Canarlian Atlantic and Pacific eonsts, for which I have used the names (i. placenta ant G. coccodes respustively. "The specific name of torenii, given by Koren and Danielssen I use as being the proper one fur this species on the authority of Hartmeyer (1915, p. 326 as Sityela lotenii).

This sperex is eiremmpolar and extenels in elistribution woll inte the subaretic on all coasts. 


\section{fionlocarpa rustlea l.,}

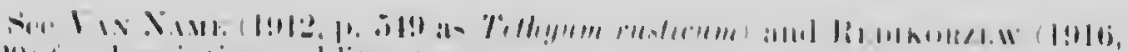

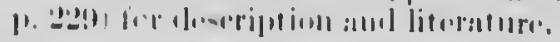

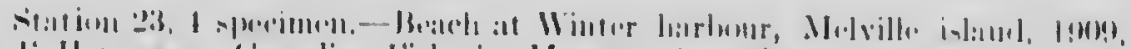

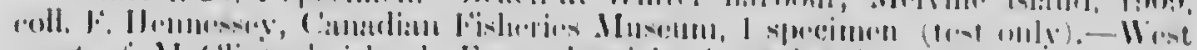

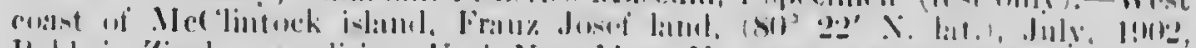

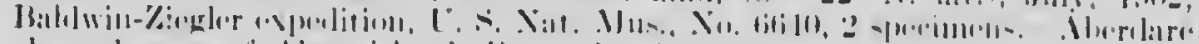

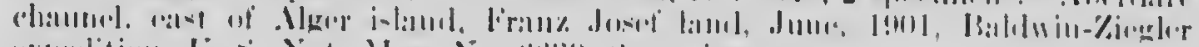

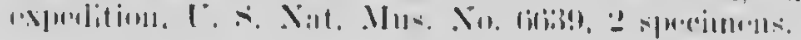

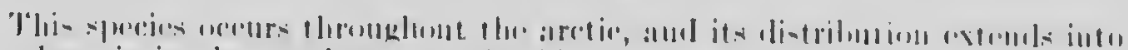

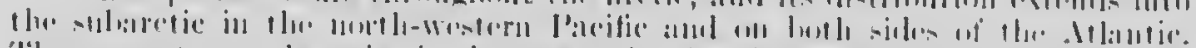

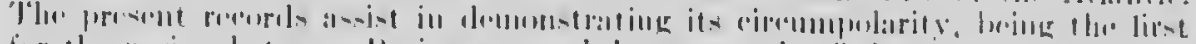

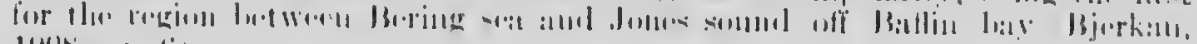
$1 ! M 14: 1,1, t i 1$.

\section{Rolteniat echlnatit $11 .$.}

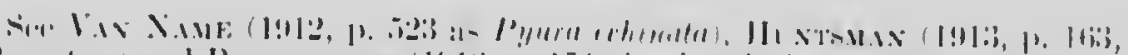

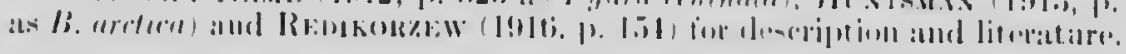

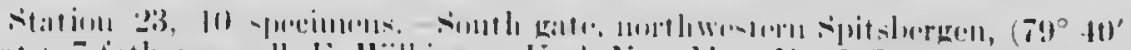

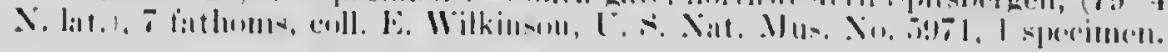

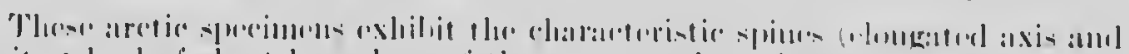

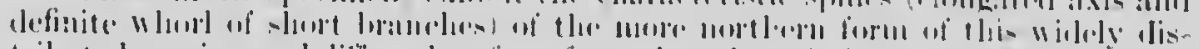

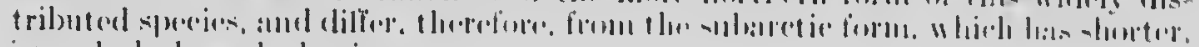
irregularly lomelanel spinte. 


\section{L.ITERATLIR:}

A rnbiset ("hristie-litude, $\Lambda$.

11. On the reproductive orknus of the Amridian Kiskenthaliu bereulis (Cottaclualdt). Proc. Zox)l. Hoxe. land. 10:1, 1p. 187-I(X).

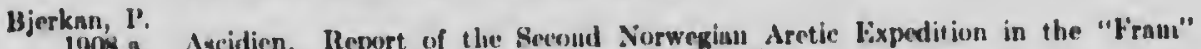

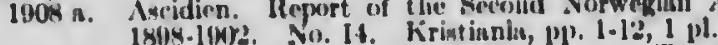

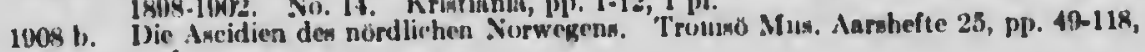
$1 \mathrm{pl}$.

Bonnevie, $\mathbf{K}$. 1800.

Ancidiac simplicen and Aseidian rompmitae from the North Atlantie lixpedition. The Norweglan Nortl Atlantle Fxped. 1876-187x. Yoxl. Vol. VII, pp. 1-16, pl. III-IV.

Hurtmeyer. $\mathbf{R}$.

1804 Dit: Monancidien der Bremer Fxperlitiun nach Ontspitzbergen iu Jalır 1889.

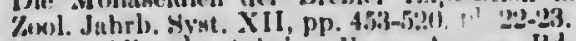

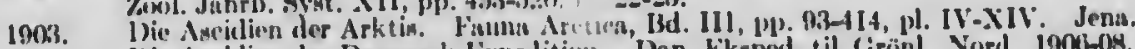
1010. Jic Ascidien der Danmark Fxpelition. Dan. Eksped. til Cirönl. Nord. 1006-08, Ihl. V, Nr. 3, Köbenbavu, pp. 22:7-2116.

1911. Nitsungsber, der Genell. nat urf. Freunde,

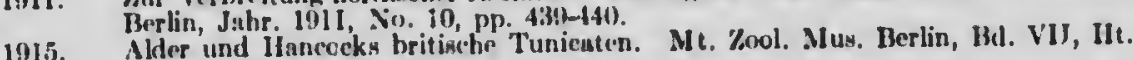
3. pp. 303-i144.

1019. Ascidicrs uus dem Barentmmerr. Arlxit. d. dentsch. v'lxecuchnft. Kummise. 1.

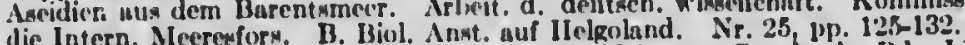

1921. Studien an westgrönlandischen Ascidien. Meddel. or Grónlani, Bd. IdXII, pp. 1-137.

Iuitfoldt-Kan, II.

1\$96. Nynascidine, Norseginn Sorth-.Itlantic Fixperl. 1876-1878. Zenl., Vol. VII, วp. $1-27$, pl. $1,2$.

Tuntsman, A. G.

1012. Ascidiuns fron the monsts of Canada. Trans. Cun. Inst., Vol. IX, p1) 111-148.

1913. Holnomatous Ascidians from the coast of western Canada. Contr. Cin. Biol. 1906-10, pp. 103-185, pl. X-XXI.

1021. Agedetermination, growth and symunetry in the teat of the Ascidian, Chelyosouna. "irans. Rov. Cun. Inst., Vul. ... ilf, No. 1, 1p. 27-38, pl. 1.

1822. Results of the Iludsin Buy Fxpedition, 1020, III. The Ascidiacea. Contr. Can. Biol., N.S Vol. 1, 1022.

Macleay, W. S.

1825. Anatomieal observations on the natural group of Tunicata, with the description of three species enllected in Fox Channcl during the lnte Northern Fxpedition. Trans. Linn. Soc. Lend., Vol. XIV, pp. 527-555, pl. XVIII-XX.

Moller, I1.I'.C.

1842. Index Molluscorum Grocnlantlise. Sat. Tidsskrift, Vol. IV, pp. 76-97.

Oka, A. Jotiaen aber japaniache Ascilien, 11. Annot. Zool. Japonmses, Vul. VIII, pt. 1914. III, pp. 14:4-458.

Redikorzew, W. 1908.

VIII Ser. Vol. XVIII, pp. 1-59, pl. I, II.

1916. Faune de la Russie. Tunicies, livr. 1, pp. 1-33tt.

Ritter, W. E.

1001. Papers from the Ilarriman ilaskn Expedition. Xxill. The Ascidians. Proc.

1913. Wash. Acad. Sci. Vol. III. pp. 225-266. pl. xxvii-xxx. The simple Ascidians from the northeastern Pacional Museum. Proe. U. S. Nat. Mus., Vol. 45, pp. 427-505, pl. 33-36.

Traustedt, M. P. A.

1886. Kara-Havets Söpunge (Ascidiae simplices). Dijmphna-Togtets zool.-bot. Udbytte, pp. 419-437, pl. 36-39.

Van Name, W. G.

1910. Compound Ascidians of the coasts of New Fngland and neighboring British Provinces. Proc. Bon. Soc. Nat. Hist., Vol. 34, pp. 339-424, pl. 34-39.

1912. Simple Ascidians of the coasts of New England and neighboring British Prov. inces. Proc. Bos. Soc. Nat. Hist., Vol. 34, pp. 439-619, pl. 43-73.

Verrill, A. E.

1871. Deseriptions of some imperfectly known and new Asridians from New England.

Amer. Journ. Science, Ser. 3, Vol. 1, pp. 93-100.

Torowro, Apr:! 
Report of the Canadlan Arctle ixpedition, 1913-18.

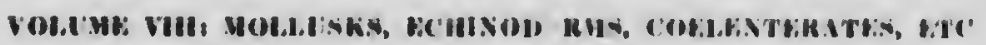

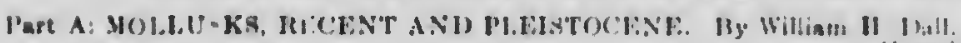

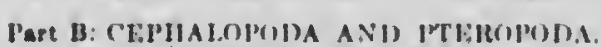

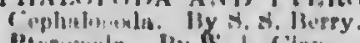

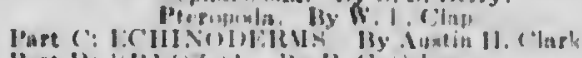

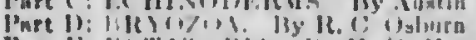

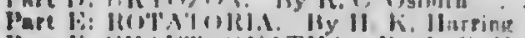

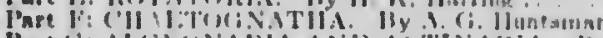

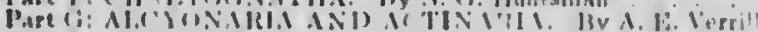

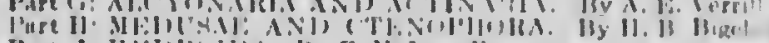

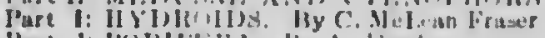

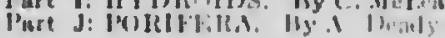

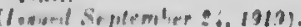

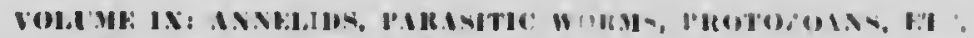

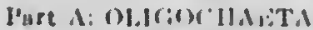

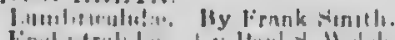

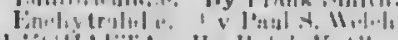

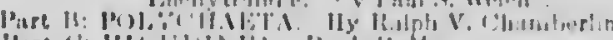

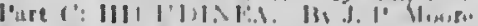

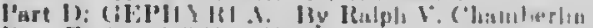

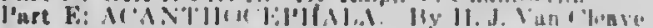

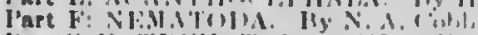

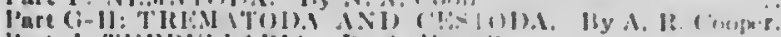

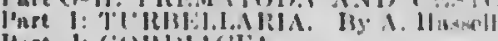

P'art J: (iviti)fir'p...

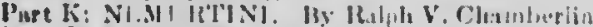

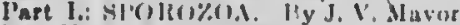

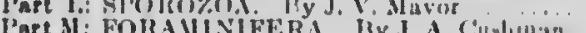

voldnt: $x$ : P.,

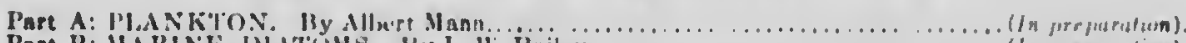

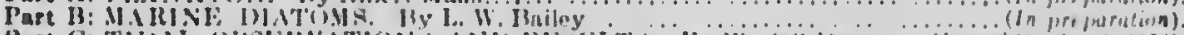

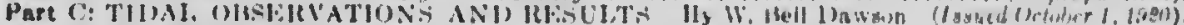

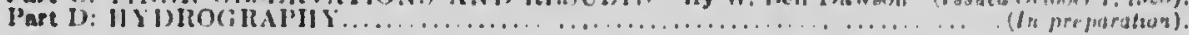

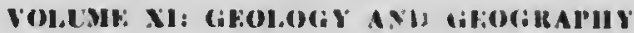

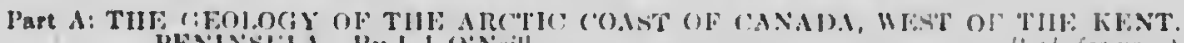

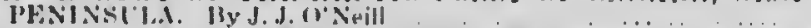

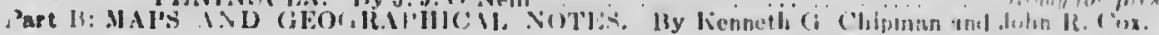

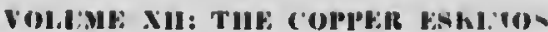

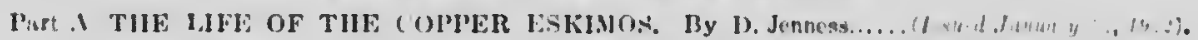

Voldme: dil: Trensolotis of THE coppll lislinos

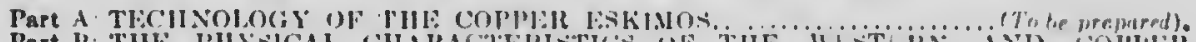

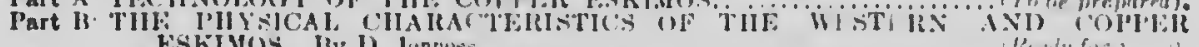

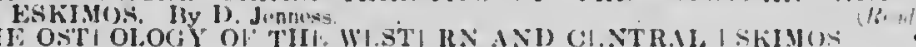

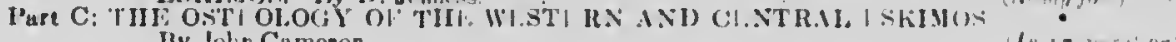

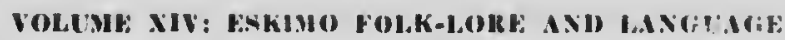

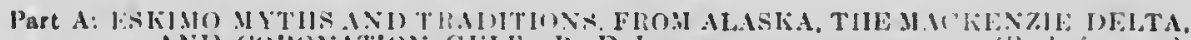

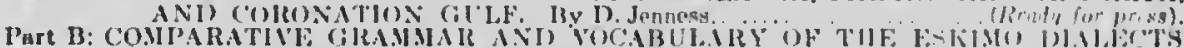

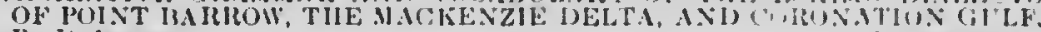

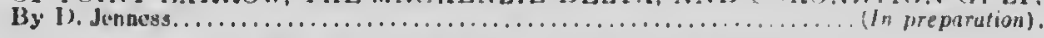

\section{VOLUME XV: ENKIMO STHNG F'GURES AND SONGS}

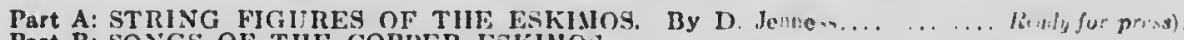
Part B: SONGS OF TIIF COPPER FSKINOS.

(In preparation).

\section{VOLUME XVI: ABCIAEOLOGY}

CONTRIBUTIONS TO TIE ARCHAEOLOGY OF WESTER. . IRCTIC AMERICA. 


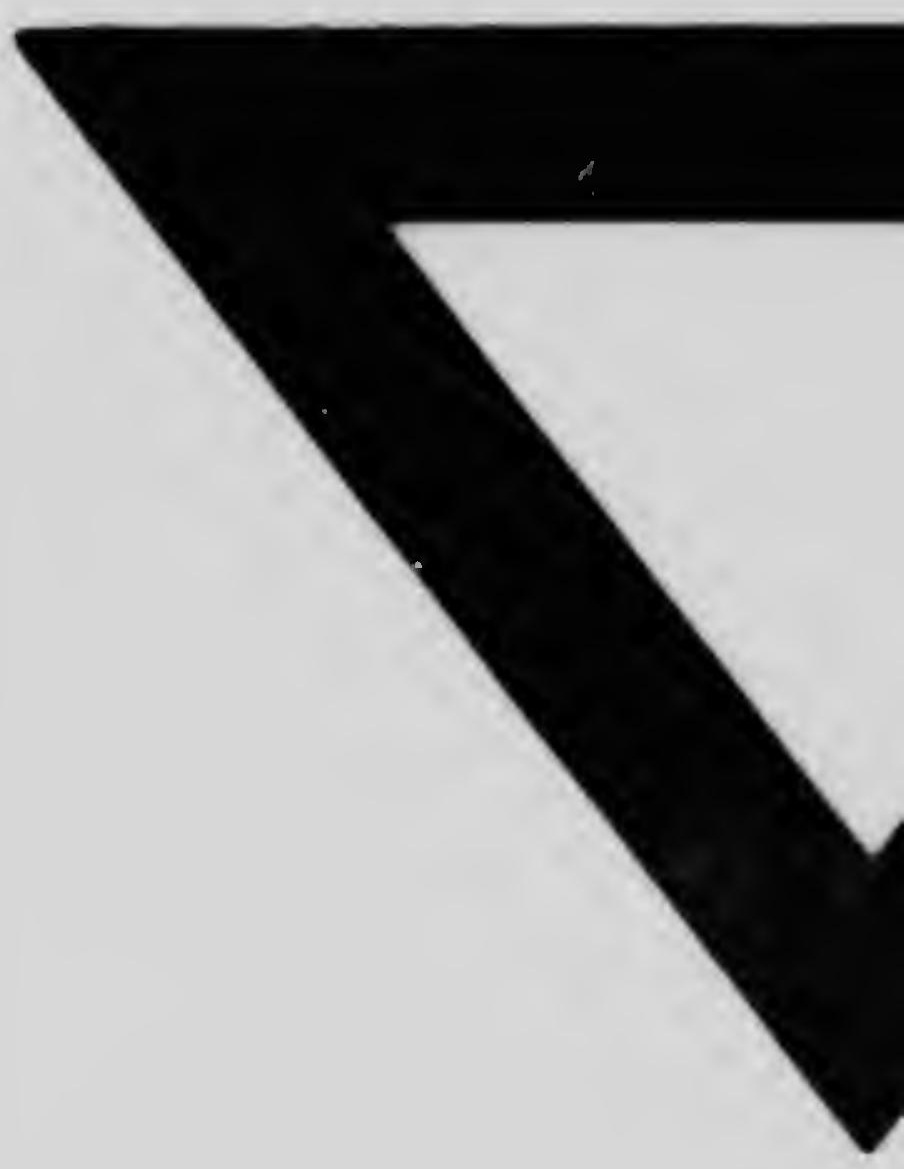




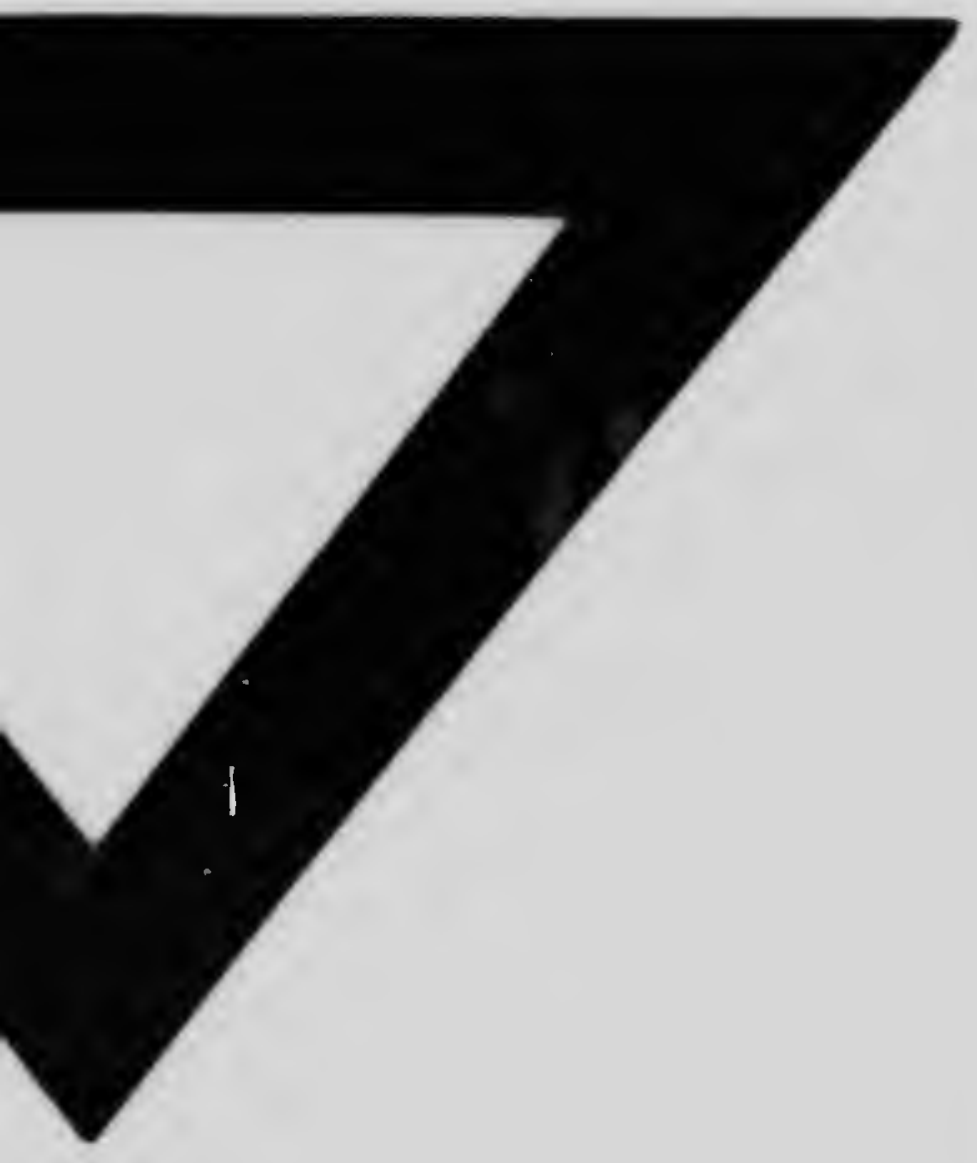

